\title{
6
}

\section{Emotions Unpurged: Antigeneric Theater and the Politics of Violence}

\author{
ANCA Vlasopolos
}

\begin{abstract}
The slaughter of the child Dionysus is an exemplary tale, whose persistence throughout multiple retellings may lead one to wonder whether... in the final analysis it does not appeal to some inclination within ourselves.
\end{abstract}

-Marcel Detienne

Recent developments in dramatic theory and in commentaries on specific authors and plays increasingly point to issues of violence and of violent exclusion. At a time in history when, on the one hand, we have been allowed a glimpse of possibilities for large-scale rearrangements of social contracts in the absence of violence, and, on the other hand, we experience rising familial and intrasocial violence, the link between drama and crisis cries out for reexamination. In 1989 central Europe underwent a revolution unprecedented in human history, and one unforeseen by most analysts of social crises. What was extraordinary about the events symbolized by the taking down of the Berlin Wall was the absence of violence. For once, collective action did not manifest itself in bloody revenge or victimization, not even, with very few exceptions, in the jailing of former leaders. (I am forced to distinguish here between events in central Europe and the unfinished-some say not yet begun-revolutions taking place in eastern Europe, most notably in Romania, Albania, and the former Yugoslavia.) In the former Czechoslovakia, particularly, the overthrow of the regime was linked with the creators of and participants in the experimental drama known as the Magic Lantern.

Yet while against all predictions violence seemed briefly to recede at the national political level for at least one region of the globe, at the "domestic" level violence continues unabated, or is on the rise. ${ }^{1}$ In a

${ }^{1}$ A graph released by the Senate Judiciary Committee, published in the Detroit Free Press, August 1, 1990, 8A, showed a projected increase in homicides from 9,110 in 1960 to 23,200 for 1990 . According to Statistical Abstracts for 1990 the actual rate rose to approximately 24,871 , or 10 homicides per 100,000 U.S. citizens. 
single two-year period these news items (some of which were reported nationally and even internationally) made the headlines of the local papers of the sixth largest metropolitan area and eighth largest city in the United States, namely, Detroit: A woman kills her only child, a fouryear-old daughter, in an attempt to punish her for "soiling herself," by placing her inside a washing machine and turning on the wash cycle. A man diagnosed as schizophrenic refuses to take his medication, brings his two small sons to his place of employment, a foundry, places them in a ladle, and burns them in the furnace. Encumbered by debts, a twenty-eight-year-old man drives his wife and four children into the Detroit River; the children all drown. A woman and her lover demand custody of her child from the child's foster parents, then proceed to beat the child to death with an extension cord. A man served divorce papers in the morning by his wife shoots her and their two sons dead on the afternoon of the same day. Two girls find a runaway girl's skinned head in a friend's freezer and bring it to the police station; the rest of her body is found buried in the backyard of a suburban home. The coroner calls it a ritual slaying. The number of children shot annually in Detroit exceeds the number of days in the year.

This summary of gruesome news should not be interpreted as an attempt on my part to provide corroborating evidence in support of the epigraph, which naturalizes myth as infanticide and makes narratives of infanticide complicit with either action or desire. Rather, it suggests that as feminists we need to reexamine the obsession with domesticity in nineteenth-century art and our late twentieth-century preoccupation with local knowledge. This shift of interest from the global to the particular can be attributed not so much to the feminization of discourse or the valorization of the underclass as to the bourgeois myth of individualism, which, by presuming that all men are created equal, moves the arena of class struggle into the family, into the minute particulars of everyday domestic life. It is here, in the familial sphere, that hierarchy in regard to women, children, and servants (we see the gradual disappearance of the male servant) still holds sway in the same unquestioned and dramatically explosive way as under absolute monarchy or totalitarian regimes. We need to scrutinize both the familial and the political stage in order to uncover societal complicity with the victimization of the powerless.

The explanation that power relations engender a "trickle-down" effect of violence-the master beats the wife, who beats the child, who kicks the servant, who kicks the dog-need not be written off as a simplistic cliché. We live in an era in which the family intrigues of the royal house, the kind that propel the plots of classical tragedies and 
impinge on the welfare of the entire community, are displaced in favor of ethnic groups and individual families, which gain importance as symptomatic indexes of the community's welfare. As Teresa de Lauretis notes: "Social science research on wife beating ... is altogether recent; and incest, though long labeled a crime, was thought to be rare and, in any event, not related to (family) violence. In other words, the concept of a form of violence institutionally inherent-if not quite institutionalized-in the family, did not exist as long as the expression 'family violence' did not." ${ }^{2}$ We perceive social disorder not merely in terms of a familial microcosm that has replaced the palace macrocosm as a reflection of the health or illness of a society, but as a lateral process, as violence among equals rather than violence spreading de haut en bas. A feminist scrutiny of the "domestic" in both its social and its theatrical manifestations is urgently needed, since this vision of society as represented by the family hides the hierarchic nature of both state and family, and it throws responsibility for disorder onto the personal or family unit in a perpetuation of the myth of individuality and equality.

Because of my family's and my personal history, which encompasses extermination, imprisonment, and exile-a history unfortunately all too common-I became interested in theater as the art form that is predicated on the representation of agon, a performance during which someone always loses, and we as spectators are expected to sympathize with the loser in a tragedy and laugh the loser off the stage in a comedy. My history has rendered me more attentive to the process of selecting a loser in drama than to the emotions traditionally elicited by the genres of comedy and tragedy. As a comparatist I am fascinated by the flexibility of theater as it exists in the West. Unlike written texts, which only sporadically become performances and which underwent drastic changes of form as the focus of representation moved from the court to the parlor, theater has retained its performative function, namely, as a collective exchange between actor(s) and spectators, whose terms to be sure are subject to the flux of cultural negotiations, but which has remained more unvaried and formalized than the readerly experience. As a woman who felt best defined politically by a UN refugee identity card stamped "Stateless," I am interested in the way in which theater accustoms us to societally decreed exile or death, especially as the home becomes the stage, and in theater itself as a more disseminated, more translatable commodity than other writings. More important, my aim

${ }^{2}$ Teresa de Lauretis, Technologies of Gender: Essays on Theory, Film, and Fiction (Bloomington: Indiana University Press, 1987), 33. 
is to discover why theater against the grain, the theater that discloses our complicity with the process of victimage, has been seen by criticsand, if we can believe the testimony of observers, by audiences-as theater that "does not work," as antitheater, as problem plays.

From its earliest connections to ritual, as well as from the literal and figurative space that theater occupied in the ancient world, we can glean its role as both reflection and reinvention of sociopolitical consensus. It is no accident that the first theoretician of theater was also the source of classical culture's most authoritative texts on the physical world and on politics, as well as the tutor to the royal scion who grew up to rule much of the known world. The stage is the world, the theater is the globe, as the Renaissance playwrights never tired of reminding their audience. When the neoclassicists used Aristotle's Poetics as a manual of theatrical good behavior, they were not misinterpreting; rather, they were reinventing theater in the context of absolute or gloriously restored monarchies. Similarly, the battle of Hernani and the experiments in England with closet drama replicated the polarization of revolutionaries and reactionaries as well as the retreat from urban public art which characterized Romanticism. Theater in the West did not begin to bridge the gap between high culture and popular culture in the nineteenth century until playwrights started to adopt the discourse developed in novels under the rubric of realism and naturalism. In other words, late nineteenth-century theater became aligned with attacks against bourgeois individualism which ironically recall ancient Delphic determinism, and as a basis for their authority playwrights borrowed the prestige of the newly ascendant scientific discourse of medicine on genetics and of natural science on evolution, particularly natural selection. In the collusion between theater and the social sciences, we see the subversion of the rationalist ideal of individualism by the new determinism, which receives its most powerful and, until recently, least examined formulation from psychoanalysis.

What interests me, however, is less the ways in which theater is complicit with the dominant interests of its time than the creation of new borders that goes on in so-called antitheater or problem plays. In order to articulate the resistance of plays such as Coriolanus, Le misanthrope, and Hedda Gabler to what I regard as our customary acculturation as spectators to the process of victimage, I need first of all to establish the link between clearly defined generic theater and the spectacle of victimization. From my point of view, such a link appears as we move from the classicist view of genre boundaries to the challenge to classicism posed by anthropological applications of the sacrificial ritual, and es- 
pecially to recent feminist redefinitions of the stage-audience contract that is negotiated through performance.

One need not, as Richard Levin insists, read theatrical texts from the parti pris of irony in order to arrive at the view that drama is par excellence a spectacle about violence. ${ }^{3}$ In Playboys and Killjoys Harry Levin summarizes the exemplary classicist position: "Conflict is inherent in all drama, and its manner of resolution-whether it favors the protagonists or the antagonistic forces, whether we exult with the victors or condole with the losers-is another distinction between comedy and tragedy." 4 The two principal mainstays of the classical position appear in this admirably terse summary: first, drama is inherently about conflict; and second, drama is divided into two genres, comedy and tragedy, which elicit opposite audience responses to the winners and, implicitly, the losers of the conflict. Tomes have been written to elaborate on these two principles, and, as I shall discuss, critical approaches to individual plays generally begin with considerations of genre, that is, with arguments about the success of the play in creating the ideal generic response of cheering the victor(s) in comedy and lamenting the loser(s) in tragedy. Moreover, arguments about audience response generate critics' analyses of characters in light of these two genres. Again, Harry Levin summarizes the classicist assumptions about genre and its heroes: "If tragedy elicits our compassion, comedy appeals to our self-interest. The former confronts life's failures with noble fortitude, the latter seeks to circumvent them with shrewd nonchalance.... The uniqueness of the tragic protagonist is marked by superlatives," whereas comedy neutralizes "tragic potentialities" (14-15).

One unstated assumption of classicists becomes apparent in Levin's statement about audience response to comedy: "Instinctively we sympathize with pleasure-seeking youth, looking through his eyes at crabbed age, feeling his distrust at whatever stands in the way of fulfilled desire" (96; emphasis added). That assumption is of course glaringly evident in a desire that Levin takes to be universal both in its manifestation and in the sympathy it elicits from the audience, namely, male desire. As feminist critics have noted, the introduction of female desire on stage finds acceptance only if it is represented as male desire in drag; otherwise it leads to problems of genre classification for critics and

\footnotetext{
${ }^{3}$ See Richard Levin, New Readings versus Old Plays: Recent Trends in the Interpretation of English Renaissance Drama (Chicago: University of Chicago Press, 1979).

${ }^{4}$ Harry Levin, Playboys and Killjoys: An Essay on the Theory and Practice of Comedy (New York: Oxford University Press, 1987), 32; subsequent citations appear in the text.
} 
audience confusion as to where to confer its sympathy, at least according to the critics who record audience reactions. As for tragedy, Aristotle's requirements for the hero in Poetics exclude women from that category entirely, although not from being portrayed as characters other than the hero, such as "wives, cousins, friends, slaves," in Gerald Else's witty elucidation of the Greek text. ${ }^{5}$ Even when they acknowledge the relation of theater to ritual, classicists see theater as transcending ritual, and consequently they invest it with civilizing power. William Gruber observes that "there is no acting without violence... nor drama without some mode of punishment," and he ruefully admits to a willed blindness about the very issue he has raised: "Trying, therefore, to be as cheerful as possible,... we might distinguish between virtual and actual victimage." Typically, he discusses audience response as identification and declares that, once identification occurs, "aesthetics suddenly becomes ethics" and "theater offers renewed possibilities for understanding the relationship between the life of a society and the strategies of its art." 6 If the whole notion of unanimous identification becomes suspect not just from a Brechtian but from a feminist perspective, theater may indeed offer possibilities for scrutinizing the relationship between society and the strategies of its spectacles.

Whereas classicists defend the transcending power of theatrical catharsis despite its problematic applicability to gender and class, critics who use anthropology to investigate ritual practices or to analyze the uses of theater emphasize the inextricable connection between theatrical violence and the sacrificial function of the ritual underlying drama. In exploring the dynamics of the narrative opposition between the Orphic account of sacrificial ritual and that of the Aristotelian school of the fourth century, Marcel Detienne concludes about Greek practice: "Political power cannot be exercised without sacrificial practice. Any military or political undertaking ... must begin with a sacrifice. ${ }^{\prime 7}$

Similarly, in tracing the secularization of Greek thought and the political transition from the absolute monarchy of Mycene to the Athenian polis, Jean-Pierre Vernant writes: "Politics, too, had the form of agon: an oratorical contest... all rivalry, all eris presupposes a relationship

${ }^{5}$ Gerald F. Else, Aristotle's Poetics: The Argument (Cambridge: Harvard University Press, 1967), 457.

${ }^{6}$ William E. Gruber, Cosmic Theaters: Studies in Performance and Audience Response (Athens: University of Georgia Press, 1986), 167, 168.

"Marcel Detienne, "Culinary Practices and the Spirit of Sacrifice," in The Cuisine of Sacrifice among the Greeks, ed. Marcel Detienne and Jean-Pierre Vernant, trans. Paula Wissing (Chicago: University of Chicago Press, 1989), 3; subsequent citations appear in the text. 
of equality: competition can take place only among peers." ${ }^{\prime 8}$ Without dwelling on societal crisis per se, both Vernant and Detienne make it clear that the illusion of equality underlying the political agon and the sense of unanimity about the sacrificial ritual were intended to avert large-scale violence by means of the contained and regulated violence of competition and sacrifice. In the first case, Vernant explains, practices that accentuated social inequality became prohibited: "What was now extolled was an austere ideal of reserve and restraint, a severe, almost ascetic way of life that obscured differences of manner and rank between citizens in order to bring them closer together" (65). In effect, social practices sustained an elaborate system of deception about the real inequality of the citizens-the male citizens, that is-precisely so as to avoid violence: "Blood revenge, which had been limited to a narrow circle but had been obligatory for the relatives of the dead man, and thus could set in motion a disastrous cycle of murder and reprisal, was supplanted by repression organized by the city... and involving the community as a whole" (75; emphasis added). A passage from Aristotle's Politics obliquely hints at the dangers of exceptionality by damning with excessive praise: "When a family, or some individual, happens to be so pre-eminent in virtue as to surpass all others, then it is just that they should be the royal family and supreme over all, or that this one citizen should be king of the whole nation.... For surely it would not be right to kill, or ostracize, or exile such a person." ${ }^{\prime 9}$ It is clear that the question of inequality with regard to gender and class arises only to be repressed in Greek thought and, as we shall see, arises only recently and sporadically in contemporary thought.

Even if the seeming unanimity of the community were granted, the ritual designed to mask the victimage was itself fraught with dangers, since if not rigorously contained the lesser violence could easily have erupted in social violence. In the case of the sacrificial ritual, Detienne writes: "There is a desire to play down the violence in the sacrificial ceremony, as if from the very outset it were necessary to disclaim any guilt of murder" (9). But, more significant for the performative aspect is his description: "On a linguistic level it is impossible to separate the one who is both sacrifier and sacrificer from the one who delegates the killing to a subordinate.... The blurring of distinctions here is fundamental. For what is hidden in this way is the naked act of violence,

${ }^{8}$ Jean-Pierre Vernant, The Origins of Greek Thought (Ithaca: Cornell University Press, 1982), 47; subsequent citations appear in the text.

${ }^{9}$ Politics, in Introduction to Aristotle, ed. and trans. Richard McKeon, $2 \mathrm{~d}$ rev. ed. (New York: Random House, 1973), 658. 
as if the features, the distinct face of the one who strikes and kills with the ax or knife were best left shrouded in darkness" (12).

Whereas Detienne concentrates on the role of presiding over and/or actually performing the ritual killing-a role that like a mask, covers up individual identity and personal responsibility-Claude Gandelman interprets the tragic mask as a coverup of the victim, "the totemic shape," "the obscene snout of the goat," which he argues is very much the same as the scapegoat of the Hebrew purification ceremony. ${ }^{10}$ There seems to be a need to disguise or leave to darkness both those who practice and those upon whom are practiced the contained violence of ritual or of theater as homeotherapy for communal violence.

Two theoreticians who combine Detienne's and Gandelman's interests and who stand Janus-like on opposite sides of the same terrain are René Girard and Victor Turner. Both accept the relation of theater to ritual, and both examine ritual and theater as moments of crisis capable of rending the social fabric. Girard, the literary critic whose passion for anthropology has transformed him into a cultural-religious sage, sees the ritual of victimage as a narrative or performance that disguises itself under a point of view that is always that of the sacrificing crowd; the only text that goes against this master narrative and undermines the unanimous point of view is the New Testament. ${ }^{11}$ Girard argues passionately for the truth of victimage narratives. He refuses them the pure invention of fantasy, since he finds that persecutors, by taking their righteousness for granted, are too naive to dissimulate. A text such as Oedipus Rex, however, needs to be stripped of its illusory logic in order to be made to disclose its sacrificial narrative. Thus we may conclude that Girard views theater as a more complicated and ambivalent setting for sacrifice than historical narratives.

By contrast, Turner begins as an anthropologist with a passion for literature, and in his cultural critique presents a much more optimistic, less Eurocentric view of ritual and theater. By examining the phases of social crisis, which in his description seem to share features of the classical-theater plots, Turner arrives at the conclusion that crisis and its resolution do not necessarily result in murderous unanimity nor in the restoration of the status quo. ${ }^{12}$ His pattern, which seemed naively sunny

${ }^{10}$ Claude Gandelman, "The Semitic Catharsis, Greek Tragedy, Christian Missa," Stand 21.4 (1977): 43.

${ }^{11}$ See René Girad, Violence and the Sacred, trans. Patrick Gregory (Baltimore: Johns Hopkins University Press, 1977), and The Scapegoat, trans. Yvonne Freccero (Baltimore: Johns Hopkins University Press, 1986).

${ }^{12}$ See Victor Turner, Dramas, Fields, and Metaphors: Symbolic Action in Human Society (Ithaca: Cornell University Press, 1974). 
a decade ago, seems to have prophesied the central European revolution of 1989-90 much more accurately than Girard's insistence on Judaeo-Christian revelation as the only path to abjuring violence. The contrast that I find significant in Turner's and Girard's expositions of societal crisis is that for Turner the crisis can move a group in a given society to a transitory utopian plane, where experimentation and creative disorder crystallize into new forms of social order, so that when the inevitable return to everyday social intercourse is reestablished, the radical changes experienced by those partaking of the utopian communitas are partially incorporated in the new order; whereas for Girard the return after the sacrificial crisis is always to the status quo, to a community dominated by fear of mimetic violence and periodically united in a murderous determination to avoid it by means of the contained violence of sacrificial ritual.

Despite these fundamental differences, Turner and Girard remain committed to a belief in unanimity, whether in the case of communitas or victimizing community, and they represent crises ultimately as the unifying agents of society in a monolithic, unproblematized way very similar to the classicists' views of audience response to genre. In effect, the unanimity they describe often consists of decisions made by leaders and followed by their dependents or prisoners, the two latter categories having no choice but to seem to go along, since their dissent either could not be articulated or remains unrecorded. In other words, the history of a crisis is always the after-the-fact inscription or remembrance of the sacrificer, not the victim. As an intended victim whose recollections are heard because his rescuers won, Primo Levi recounts the historical foresight of his would-be butchers:

However this war may end, we have won the war against you; none of you will be left to bear witness, but even if someone were to survive, the world will not believe him. There will perhaps be suspicions, discussions, research by historians, but there will be no certainties, because we will destroy the evidence together with you. And even if some proof should remain and some of you survive, people will say that the events you describe are too monstrous to be believed: they will say that they are the exaggerations of Allied propaganda and will believe us, who will deny everything, and not you. We will be the ones to dictate the history of the Lagers. ${ }^{13}$

Thus, for someone like me, Girard's seeming exception, the New Testament, represents not the scapegoat story told from the point of view

\footnotetext{
${ }^{13}$ Primo Levi, The Drowned and the Saved, trans. Raymond Rosenthal (New York: Simon \& Schuster, 1988), 11.
} 
of the victim, but the victory of Judaeo-Christian religion over older or concurrent forms of worship, such as Wicce or the Gnostic Gospels, whose practitioners were systematically victimized and whose alternative narratives were silenced by the Church Triumphant.

If we examine the operations of ritual and theater from the angle not of the silenced victims but of those excluded from participation, we discern the hierarchy that dominates both performances and hides under the mask of unanimity. In regard to ritual, Detienne's examination of Thesmophoria reveals both the exclusivity of sacrificial rituals in the Greek city and Greek men's fearful imaginings about the single festival celebrated only by women. First, the ritual within the city: "With respect to sacrifice, it is the female population that forms the most important category of marginals.... They are kept apart from the altars, meat, and blood ... they are admitted into the larger circle of commensals only by the intermediary of someone having the right to obtain for them this favored treatment. At a sacrifice, particularly a blood sacrifice, women cannot function as full adults." Yet, despite the clear separation between the category "woman" and blood sacrifice, which extends to a linguistic barrier-" "the word [mageiros] has no feminine form ... the Greek system does not allow any thought of women as butchers and sacrificers" - narratives about Thesmophoria indicate not only a preoccupation on the part of men to identify "woman" but a deeply ingrained fear of what women may do when they escape from under the control of male hierarchy. As Detienne relates:

This fear, which attributes homicidal—or "androcidal"-projects to the most domestic of women is ... reborn in the contradiction manifest in a festival in which women among themselves are assuredly the exemplary "lawful wives" of citizens but in which a city, now the exclusive property of women, at last possesses the weapons of sacrifice and thereby threatens the "other" city-all the more so because the strictly male prerogative to kill and slaughter has fallen into the hands of the best of the race of women. ${ }^{14}$

Significantly, this feared group of marginals comprises only the protected, respectable women of the polis. Nothing is said on the subject of those who, in addition to being women, also threaten the hierarchy by remaining unassigned, so to speak, to the ownership of any one male and who therefore have no legal right to representation or to sacrificial meat. May not these undifferentiating, anarchic agents, who,

${ }^{14}$ Marcel Detienne, "The Violence of Well-Born Ladies: Women in the Thesmophoria," in Detienne and Vernant, Cuisine of Sacrifice, 131-32, 143, 147. 
despite their imaginary power, are forbidden access to weapons, become themselves the ideal target of victimage? And since Detienne himself depends for his investigation of Thesmophoria on narratives of the imaginary, may we not see theater as the meeting place of hierarchical order and the hallucinatory fear of the "other"?

Detienne's suggestive speculations receive ample support from Page duBois's Centaurs and Amazons, an extensive study of the link between gender and hierarchy in Greek thought and in classical-theater representation. DuBois posits a shift in discourse from Aeschylus to Aristotle that can be briefly, and I hope not reductively, summarized as constructing difference through analogy versus constructing difference by hierarchy. She dubs these modes literary/poetic and philosophic, respectively, and she reads in both an obsession with boundaries, which changes focus from seeing the world divided into enemies without versus Greeks within to an attempt to discover the enemies within the polis and even within the sacred space itself. Occupying the category "enemies," centaurs, Amazons, and foreigners were seen to hold in common a disregard for "ordered festivity." But this necessity of identifying the enemy within, which, as we shall see, is the driving motive for the process of victimage, may work in the same way as the imaginary narratives surrounding Thesmophoria, that is, those most likely to find themselves as victims on the altar and those excluded from contact with the weapons of sacrifice become the ones charged with disrupting or inverting the sacrificial economy. DuBois writes: "If, in the changed social and economic situation, the enemy was discovered within, a new rationalization of internal political control was necessary; the theory of natural hierarchy is that rationalization." Her conclusion serves to bring to the fore some of the reasons why issues of gender, class, and foreignness (which includes race) have so often not entered classicists' considerations of the unanimity of audience response and social crisis interpreters' views of societal consensus: "The project of this philosophy, from its earliest expression in Plato and Aristotle, was from its beginnings centered on questions of hierarchy, of mind over body, man over woman, "human" over foreigner, over slave. The model of dominance, with its concomitant dualism, as a description of natural relationships in all cases, survived as a defining structure in post-Platonic and post-Aristotelian discourse." ${ }^{\prime 15}$

Indeed, this model of dominance, as Sander Gilman shows, survives in the dominant scientific and medical discourses of the nineteenth and

${ }^{15}$ Page duBois, Centaurs and Amazons (Ann Arbor: University of Michigan Press, 1982), 29, 145, 152 . 
twentieth centuries, in which difference is defined as pathology and is exemplified by sex, race, and class. A merging of the three as a marker of pathology appears in law courts, fiction, and the visual arts, as well as in late nineteenth-century theater. ${ }^{16}$

The complicity between theater and patriarchal order has not escaped feminist critics of drama. The dominance of the Aristotelian discourse in dramatic theory has, however, led to an attempt by many simply to write off all theater except for feminist-written or improvised and feminist-produced all-female performances. Although this rather separatist move (I use the qualifying "rather" because some feminist theater critics do preserve vestiges of Marx and Brecht in their prescriptions for a new theater) does raise issues of audience division and performative subversion, it nevertheless remains caught in the problematics of essentialism. Both Sue-Ellen Case and Jill Dolan, for instance, examine the myth of audience unanimity succinctly. On the basis of Aristotle's definition of women and slaves in Poetics and Politics, Case declares: "Denied tragic qualities, cleverness, authority of deliberation and the right to speak, women seem to be excluded from the dramatic experience." She sees a parallel between theater and society: "Along with the suppression of the public appearance of the female gender, its metaphorical appearance in cultural productions became suppressed as well: the absence of women's voices in literature, philosophy, theology and other branches of learning was the counterpart of their absence from [church] choirs and the stage." There is, however, a danger in equating the world with the stage: archival studies by feminist scholars have unearthed abundant evidence of women's voices in fields previously regarded as the exclusive preserve of men. The question of interrupted transmission, of course, remains. For Case, the emergence of women on stage does not mitigate what she calls "the alliance of theatre with patriarchal prejudice," since when women do make their appearance, they fulfill the "fiction of the female gender," representing the gendered female body rather than a genuine female point of view. ${ }^{17}$

Dolan goes even farther in denying not only the idea of audience unanimity but the very notion of identification being possible for the feminist spectator, who "sees in the performance frame representatives of her gender class with whom she might identify-if women are represented at all-acting passively before the specter of male authority."

\footnotetext{
${ }^{16}$ Sander Gilman, Difference and Pathology: Stereotypes of Sexuality, Race, and Madness (Ithaca: Cornell University Press, 1985).

${ }^{17}$ Sue-Ellen Case, Feminism and Theatre (London: Macmillan, 1988), 18, 21, 19, 27.
} 
The only position Dolan envisions for the feminist spectator is one of critical distance, a female Brechtian alienation: "A materialist feminist critique can recuperate some of [Brecht's] theories to focus on representation's perpetuation of social relations of gender, race, and sexuality, as well as class." ${ }^{\prime 18}$

My own difficulty with this position is twofold. First, a categorical rejection of empathy that speaks for all feminist spectators silences dissent in the same way as the classicists' assertions about audience identification with male desire. I am not willing to relinquish my viewpoint as feminist spectator because at certain performance times I have identified with a female character in a play. I think that Dolan and Case deny the subversive power of a great actor, director, or ensemble, which can undermine and explode any designs that patriarchal intent may have had in the construction of the play. Second, if the position of the feminist spectator is always that of the outsider able to deconstruct the culture, just where is that privileged "outside" which allows the feminist spectator to remain immune to the influence of her own culture in the construction of her own gendered, racial, class-bound self? I believe these acts of transcendence are easier to theorize than to practice. Perhaps more useful to my own recuperative project is Barbara Freedman's more problematized approach to genre and to the tension between what she calls "narrative drama," the male plot, and " theatricality' or "performance,'" which can function so as to disrupt the former. Initially, she too gives us a classicist position à rebours in regard to genre: "As with our political party system and our gender system, traditional Western theatre offers us only two stages, comic and tragic, upon which are always playing some version of Oedipus or its sister play, The Taming of the Shrew." Yet Freedman recognizes that while agonistic theater needs the mask of gender and class, it also "points to the masquerade." Moreover, she concludes that theater through spectacle manages a space not strictly bound by language, where surprising reversals can occur: "Theatre is the place where a male ruling class has been able to play at being the excluded other.... If theatre has offered men a chance to identify with the place of a mother's look, to imitate the mother's desire, and to control the woman's looking back, theatre also offers the opportunity to reframe that moment from a point of view alien to it." ${ }^{\prime 19}$

${ }^{18}$ Jill Dolan, The Feminist Spectator as Critic (Ann Arbor: UMI Research Press, 1988), 2, 107.

${ }^{19}$ Barbara Freedman, "Frame-up: Feminism, Psychoanalysis, Theatre," in Performing Feminisms, ed. Sue-Ellen Case (Baltimore: Johns Hopkins University Press, 1990), 58, 60, 74 . 
We can see the moments of unease, of generic slippage, in theater as the cracking of the mask that reveals the masquerade beneath it and with that revelation puts into question the stability of assumptions about genre, which after all are assumptions about unanimity on issues such as gender, class, and race. Once put in question, this illusory unanimity, which represents the required first step toward the process of victimage, can be shattered, and the effect that Brecht much after the fact describes as alienation can break up the audience's unity of emotion, can transform the audience from mob to uneasy individuals aware of their differing, ambivalent, complex reactions to the spectacle before them. In transgressing the boundaries of genre, and implicitly of the social hierarchy supported by genre, antigeneric theater serves as the limen, that unstable and undefined border that offers both a critique of the status quo and a provisional glimpse of what a different social arrangement might be. In the twentieth century, in which the antigenre becomes normative, we see at least one instance of the victimized becoming president of a republic. But before we can rejoice in the transformative power of the critique and of the practice of nonviolence, we must remember that political revolutions have remained for the most part all-male affairs, as the theater (with few, but more and more visible, exceptions) remains a predominantly male art form.

Where, why, and how do those moments of generic blurring, which question hierarchic arrangements based on victimage, occur? In attempting to arrive at answers, will I be defining a third theatrical genre or redefining the hybrid that we encounter in theater history as tragicomedy, mixed-genre play, dark comedy, problem play, bourgeois tragedy? Like any contemporary critic I am beset by a sense of belatedness in undertaking a discussion of genre. Jean-Marie Schaeffer argues that "a radical change in conception [about genre] occurred toward the end of the eighteenth century; henceforth literary theory would no longer be conceived as a descriptive and/or normative activity but as a speculative, interpretive undertaking. ... The objective of the generic theory was to interpret the existence and intrinsic organization of this new object: why and how does literature exist?" Though I would disagree with his interpretation of the classical era as one in which a "hierarchy [among genres] is purely axiological and does not lead to a global logical structuration or to a system," the question with which I began this section places me squarely in the wake of the "radical change" that Schaeffer detects at the end of the eighteenth century. Nevertheless, in speaking of antigeneric theater as a genre, I am in complete agreement with Schaeffer's analysis of the relation of genre and individual text: 
"Every text, inasmuch as it is grasped in its genesis, is always logically either posterior or anterior to a given generic classification. . . Far from being definable with the aid of genre, it is the individual text that decides, in part, what a contingent ulterior generic definition will be." 20 He concludes that, being inevitably retrospective, generic classification cannot be interpretive; yet in the history of dramatic criticism, generic classification has always had not only an interpretive value but the power to lend legitimacy and respectability to individual texts. ${ }^{21}$ Schaeffer's argument about text and genre, however, can be usefully applied to moments in the history of theater such as the almost universal declaration in the twentieth century of "the death of tragedy," which represents a break in twentieth-century theater from retrospective generic norms toward a norm whose very plethora of names (theater of cruelty, theater of the absurd, street theater, guerrilla theater, living theater) shows the undecidability and multiplicity of its generic conventions. I would, however, argue for antecedents to this twentieth-century antinorm, plays that anticipate the slipperiness of genre by breaking the generic codes that they themselves summon only to betray, with the effect of producing the unease that begins to crack the ideology of classical genre.

The plays I have chosen as representative are firmly entrenched in the canon of theater. It may seem peculiar for a feminist critic to devote herself exclusively to a comparative analysis of drama written solely by male authors, and canonized male authors at that. Yet as a feminist and comparatist I hope always to labor in the shadow of my obsolescence as critic. The issues that unite, divide, and continue to consume us, issues eminently present in these plays, will, I hope, be superseded by future generations, and the forms of their theater be as incomprehensible to us as our preoccupations will be to them. On that utopian note, let me turn to the specific topos of the three plays I have selected: Coriolanus, Le misanthrope, and Hedda Gabler. ${ }^{22}$

In the context of a generic breakdown and the resultant confrontation

${ }^{20}$ Jean-Marie Schaeffer, "Literary Genres and Textual Genericity," in The Future of Literary Theory, ed. Ralph Cohen (London: Routledge, 1989), 168, 169, 175.

${ }^{21}$ See Dolan, Feminist Spectator as Critic, 22, on the Aristotelian pedigree that Robert Brustein felt compelled to give Marsha Norman's play 'night, Mother so that it might be considered serious theater.

${ }^{22} \mathrm{I}$ am at work on a study of antigeneric drama which will include the three plays mentioned here and two twentieth-century plays, discussed extensively in my essays, "Authorizing History: Victimization in A Streetcar Named Desire," Theatre Journal 38.3 (1986): 322-34, rpt. in Feminist Rereadings of Modern American Drama, ed. June Schlueter (London: Associated University Presses, 1989), 149-70; and "The Perils of Authorship in Le voyageur sans bagage," Modern Drama 29 (1986): 601-12. 
of the audience with an imperfectly masked process of victimage, these three plays present continuities in terms of resistance to genre while at the same time they are discontinuous in regard to culture-specific features. I do not wish to argue that these plays are exemplary of antigeneric theater, since I hope that if my methods and aims in this investigation gain credence, a reader may come up with equally representative selections of plays that have resisted genre and, implicitly, the unanimity of response ideally elicited by classical tragedy and comedy. In addition, I hope that we might gain enough wisdom from history so that as active participants in performance-actors, director, audience-we may deconstruct such "exemplary" texts as The Merchant of Venice, as has, in fact, been the case in post-World War II productions of the play. ${ }^{23}$ In other words, despite valiant efforts by Richard Levin and Northrop Frye to make us accept Shylock as the traditional Renaissance vice and thus quiet our unease, it has become increasingly difficult not to hear echoes of the contemporary meaning of ghetto and not to see in the black-clad figure the concentration camp scapegoat of European civilization. We can only hope that other exemplary texts such as The Tempest and The Taming of the Shrew will produce, and be produced with, the same representational unease.

The plays that I have selected have in common a number of salient points that prove particularly fruitful for a comparative analysis. First, in each the focus directs itself relentlessly to the hero; there are few if any scenes in which the hero is absent, and there are virtually no subplots. Despite this intense concentration of plot on the hero's actions and presence, she/he never rises to tragic stature or descends to the status of comic vice. Thus, in traditional generic terms there is no tragic fall or comic expulsion. Second, the hero lives in a period of sociopolitical and economic crisis that she/he exemplifies or embodies. Third, the hero insists on sociopolitical and ethical distinctions in a historical moment when society is on the brink of dissolving or altering those very distinctions. Ultimately, what these plays have in common is the place they hold in my consciousness as "sore thumbs" of canon and repertory. It is not surprising that three plays written before the twentieth century have enjoyed more of a vogue in contemporary late twen-

${ }^{23}$ For instance, a 1974 television production of Merchant, with Laurence Olivier in the role of Shylock, ends with a cantor's voice singing the kaddish, the traditional Jewish prayer for the dead. This superimposition not only suggests Shylock's death and his daughter's remorse, but turns the traditional golden comedy reconciliation into a view of assimilation, for both Jessica and Shylock a kind of death, figurative in her case and literal in his. 
tieth-century repertory, in which generic breakdown is far less startling, than in their own time.

I do not want the solidus in she/he to obscure the fact of gender, which becomes more self-consciously complicated as we move into the nineteenth and twentieth centuries. I have deliberately chosen to refer to the main character in each play as the hero, regardless of gender, because the word protagonist should be used sparingly in the case of these problematized heroes, and the word heroine connotes passivity: the heroine is the figure the hero sets out to rescue. In fact, the question of gender, which is explicitly raised in Hedda Gabler, is intricately tied to the critique of genre ideology posed by these plays. Whereas in Coriolanus and Le misanthrope Shakespeare and Molière use gender differences and the collapse of these differences to opposite ends but without offering a direct critique of the very notion of gender differentiation, in Hedda Gabler victimage is represented in ways that are further problematized by the questioning of gender identity which cuts across class differences.

Both Coriolanus and Le misanthrope bring up issues of hierarchy, differentiation, and lack thereof, and treat the problem of disposing of individuals who, as Aristotle puts it, are "pre-eminent in virtue." It is no use arguing that Coriolanus and Alceste are unpleasant persons; that characteristic, decidedly, is a component of exceptional virtue, and should not be, as Aristotle seems to tell us, a criterion for exile in a just society. Yet their very unpleasantness, especially that of Coriolanus, provokes a desire on the part of the audience to approve of the victimage inexorably taking shape in the plot. Coriolanus is not an Oedipus or an Othello or a Lear whose fate we can lament as a means of reconciling ourselves to the inevitability of making scapegoats of outsiders or of dispossessed old people. ${ }^{24}$ The play confronts us with our own intolerance by presenting us both with the spectacle of a country putting itself in jeopardy because it cannot tolerate the very virtù it extols, and with our own desire to comply with the sacrifice of so unlikable a hero. We are allowed to lament Othello's fall from power through Iago's manipulations without acknowledging that Othello is never more

\footnotetext{
${ }^{24}$ In Totem and Taboo, trans. James Strachey (New York: Norton, 1950), Freud postulates that tragedy reenacts the primal horde of brothers killing the father and sees the tragic spectacle as a "systemic distortion," as "the product of a refined hypocrisy" in which the victim is responsible for its victimage and the killers console themselves with laments for their victim (156). Although I agree with his deconstruction of tragic guilt, his fantasy of the primal horde is a projection of adult males fearful of losing power onto the children they would forestall from growing up to supplant them. The tragic hero combines features of the father with the status of orphan child, the latter being the chief figure of the dispossessed in Western literature.
} 
than a pawn, used by the Christian Venetian Republic to hold his own people at bay or to help conquer them; his susceptibility to Iago stems from his already marginal position as exotic monster. King Lear allows us to lament the fate of dispossessed old men when in reality it is daughters and bastard sons who are dispossessed and sacrificed by powerful old men; thus the sacrifice we lament obtains our acquiescence to the further oppression of daughters and bastard sons, which in the universe of King Lear seems merited.

In Le misanthrope Alceste defeats comic expectations, as much as Coriolanus deviates from tragic expectations in Shakespeare's play. Alceste is neither the jeune premier, exemplary of youthful male desire, whom Harry Levin's audience presumably wishes to see triumph over elderly blocking agents, as if romance were an agon between young and old men, not the coming together of sexually attracted partners; nor is Alceste a Malvolio, easily relegated to his dark prison and then ruthlessly exiled from the joyous new order. The ambivalence we feel toward these heroes cracks the mask and allows us to perceive the plots of tragedy and comedy as the oft-repeated tales that make us acquiesce to selective slaughter, so long as we, as the Greek chorus iterates, lie low, pretend to equality, take refuge in mediocrity, and thus escape notice.

In Coriolanus the societal crisis with which the play opens requires a victim, and from the very first scene we are witness to the connection already established in the mob's mind between Coriolanus, commensal equality ("Let us kill him, and we'll have corn at our own price"), and excessive virtue ("What he hath done famously he did it to that end"), that is, the kind of grating, explicit excellence that disturbs the illusion of equality to the point of negating it. Much has been written about the class struggle in Coriolanus, but no commentator has noted the unity of purpose of patricians and plebeians, the near-unanimity about the victim, which is expressed in united attempts by patricians and plebeians to point to Coriolanus' eccentricity and exceptionality. ${ }^{25}$ In fact, it is the patricians, not the plebeians, who "monsterize" Coriolanus in order to render him fit for the sacrifice. But in what sense is the first warrior of the nation a marginal character whose sacrifice contains rather than spreads the violence of the crisis? The most interesting, because least expected, among the general accusations brought against the potential victim is the accusation that Coriolanus' virtue is not manly: "What he

${ }^{25}$ See Kenneth Burke, Language as Symbolic Action: Essays on Life, Literature, and Method (Berkeley: University of California Press, 1966), 86-87; Paul A. Cantor, Shakespeare's Rome: Republic and Empire (Ithaca: Cornell University Press, 1976), 57; and Norman Rabkin, Shakespeare and the Problem of Meaning (Chicago: University of Chicago Press, 1981), 111. 
hath done famously ... he did it to please his mother." It becomes clear that Coriolanus, like Oedipus, is a young man without patriarchal relations. The figure of Volumnia as the unhoused wrath of "the best of the race of women," as Detienne describes lawful wives, becomes the focus of the greatest unease in the play. Her son is her power, her right to virtue and to commensals, and his link to her rather than to surrogate fathers in a society personified through Menenius' tale of the belly as a body without a head disrupts hierarchic arrangements more strongly than the plebeians' demands for representation. We never see Volumnia in her own house; in the only domestic setting, with Virgilia, she tries to tempt the young woman out of her womanly occupation. When she engages Virgilia on her side in the brawl of words with the two tribunes, they are in the street, and their public anger makes Sicinius ask, "Are you mankind?" - a question that will shortly be asked about Coriolanus in his role as Volscian general. The Amazon, the beastly, the nonhuman, and the foreign have combined into the enemy that attacks from both within and without. Only when Volumnia acknowledges her rightful habitation and name, that is, when she describes herself as the womb of patria, does she regain her status as Roman matron and participant in her son's sacrifice.

Coriolanus suffers first exile and then death through metaphorical emasculation, which implicitly restores social balance by a proper redefinition of gender roles. Just as the "altitude of his virtue" is interpreted by the Roman populace as part unmanly attachment to his mother and part self-serving gesture, so his exile is interpreted by the patricians and by Aufidius as lack of control. Before his death he is accused again of unmanly regard for "his nurse's tears" and is verbally reduced to a "boy of tears." His overt emasculation, combined with his having severed his ties to his patria, qualifies him for the role of sacrificial victim whom no one will avenge. His murder restores the illusion of equality in both Roman and Volscian societies, since neither side now possesses an invincible warrior whose singularity provokes envy and fear; it also more subtly but significantly restores the proper hierarchy of the sexes with the apotheosis of Volumnia and Virgilia as the matrons whose womanly appeals saved the state and deprived the widowed mother of her too powerful champion.

Conversely, in Le misanthrope, which depicts a society in which the desideratum is the metaphoric and economic emasculation of the nobility, traditionally "male" values create a potential for violence that must be contained; throughout the play the means of control is a ritualized choreography of social bienséances. I use the dance metaphor deliberately, taking my cue from the court dances that emphasized the 
interchangeability of partners and the necessity of not fixing on any one partner. The person who refuses to dance in step is literally expulsed. The sublimation of violence in a code of rigidly structured social constructions has its parallel in instances of extreme violence of language (interestingly, less on Alceste's part than on the other characters') contained in the formal and stately alexandrines. Perhaps the most explicit moment of rivaling discourses that the play exposes is the contest between Oronte's generic sonnet and Alceste's much more culturally specific ballad. Critics have regarded the affair of the sonnet as an example of Molière's genius at creating an absurd farcical situation.

The matter of the sonnet, however, becomes the subject, on the one hand, of a serious critique of the language of sentiment at and around the court of Louis XIV and, on the other, of a satire of the legal system, a satire that is sustained in the rest of the play as well and that has received little critical attention. The trials of Alceste, in both senses of the word, seem marginal to the romantic plot, but they determine the sacrificial character of Alceste's exile. In the first instance, Oronte presents Alceste with an unexceptionable love sonnet that captures every convention of the times. The classical names themselves, like those in Molière's comedy, are interchangeable, identified only by gender. The sentiments expressed strike the proper balance of a desire nicely contained by wordplay. When Alceste counters with his ballad, he names names (of king, of city) and invokes an aesthetic of excessive passion that not only is disinterested-it refuses the exchange of the city of Paris for one's love-but that putatively defies the king, albeit Henry IV and not the present one. Typically, Alceste resists and even combats the principle of interchangeability which keeps court hierarchy strictly dependent on the king's notice rather than on personal merit. He places private passion and loyalty above the public necessity of bienséance, of an undifferentiation that reminds us of the Greek polis and the ideal of sophrosyne.

Similarly, in the matter of his procès, Alceste again places himself in opposition to the forms required by his social milieu. He refuses to solicit the judges, letting his case stand on its individual merit. When he loses this trial, a loss foreshadowed by his loss of the earlier trial about Oronte's sonnet, he is forced to flee so as not to be thoroughly dispossessed and imprisoned. This outcome of the legal system is often overlooked by critics, who feel that Alceste's decision to retire from society is purely personal, based on his failure to impose his ways on everyone, including Célimène. ${ }^{26}$ But if Molière intended a critique of

${ }^{26}$ See J. D. Hubert, Molière and the Comedy of Intellect (New York: Russell \& Russell, 
court society and of the legal system, he could hardly have made it central to his play. The only way he could introduce it would be through oblique references to Alceste as a man pursued by the law. Instead, the central discovery in the plot of Le misanthrope is Célimène's betrayal. This centerpiece is an extraordinary tour de force in Molière's play since it exposes precisely the kind of interchangeability to which Alceste has been objecting throughout; the lovers become in turn an excuse for Célimène's exercise of wit. She uses differentiation only to ridicule them, thus in effect to level them again into a heap of equally hopeless aspirants to her hand. The speed with which all the lovers but Alceste turn on her indicates the submerged craving for the kind of personal differentiation forbidden them by their society and underlines the collective desire for victimizing the rule breaker. Neither Célimène nor Alceste is chosen at random as victim; the first is an unprotected woman who, unlike Arsinoë, seems not to have powerful connections, and the second is a man who is on the wrong side of law and who declines to seek influence at court. Unlike the woman, whose breach, though spectacular, is confined to a single detected instance, the man, who reminds this assembly of petty aristocrats of their loss of personal distinction, is continually both sought after and reviled, and ultimately he serves as scapegoat, taking into the desert the unpardonable vice of unmasking everyone's forbidden desire for individuality.

There are critics who regard any defense of Alceste as a Rousseaulike romanticizing of a farcical hero, yet whose very insistence that we should have no sympathy for Alceste points to the fact that Alceste elicits divided responses as honnête homme and as object of desire. ${ }^{27}$ Unless we are prepared to accept every other character in Le misanthrope as a type of humor or a clown, we have to account for Alceste's attractiveness insofar as the other characters are concerned. He is perpetually being courted by men and women who seek to be distinguished, individualized, by his regard. Ironically, their very pursuit of Alceste makes them less individuated, since the foolish and obnoxious Arsinoë and Oronte, as well as the honnêtes Philinte and Eliante, strive to obtain or maintain his esteem. The only way in which Alceste makes himself ridiculous is in his role as lover of a woman who refuses as adamantly

1962); and James F. Gaines, Social Structures in Molière's Theater (Columbus: Ohio State University Press, 1984).

${ }^{27}$ For the opinion that Alceste is purely comic, see Lionel Grossman, "Molière's Misanthrope: Melancholy and Society in the Age of the Counterreformation," Theatre Journal 34.3 (1982): 323-43; Nathan Gross, From Gesture to Idea: Esthetics and Ethics in Molière's Comedy (New York: Columbia University Press, 1982); Roger Ikor, Molière double (Vendôme: Presses Universitaires de France, 1977); and Robert McBride, The Skeptical Vision of Molière: A Study in Paradox (New York: Barnes \& Noble, 1977). 
to distinguish between him and her other lovers as he adamantly refuses to accept the bienséance of interchangeability. But, unlike Malvolio, Alceste is not laughed off the stage as the unsuitable lover. He is chased away by the law, and our last glimpse of him is of his being in turn chased after by the two most typically reasonable characters in the play, Philinte and Eliante, who hope to persuade him to return.

With Hedda Gabler we arrive at a late nineteenth-century variation on Molière's critique of a society in which individual differences are reduced to the frequency of one's attendance on the king's bodily functions. Ibsen presents us with a virulent portrayal of a bourgeois invention, the romantic triangle, a situation that presumably heightens individuation and desire, but in Ibsen's play is exposed as a suffocating, self-perpetuating domestic arrangement in which individuals merely take their places and are at best able to change positions, but which they cannot escape without being victimized. In his choice of an upperclass hero who chafes not only at middle-class values but at gender expectations, Ibsen takes up the class and sex issues that preoccupied nineteenth-century society. By choosing the unconventional woman as an aristocratic leftover soon to be disposed of, many writers of the period were able to remain politically pure in their allegiance to the bourgeoisie and at the same time to deal a blow to the notion of female enfranchisement. Ibsen, however, evades this mode of stereotyping. Instead of presenting class and sex as weak-willed, morally corrupt, and parasitic upon the energetic nouveaux bourgeois, Ibsen reduces the characters in Hedda Gabler, regardless of their sex, age, and class, to rivals and objects of desire.

The play makes clear that Hedda's suicide has nothing to do with either of the popular bourgeois themes of late nineteenth-century art: aristocratic degeneracy and/or lack of true womanliness. The interchangeability of participants in the triangular mobile of desire which Ibsen constructs levels any claims to superiority that the middle class might make and subtly undermines the sex-role differentiation imposed by the bourgeois division of public and private spheres. By removing or eliminating one member of the triangle, obsessive rivalries produce victims, so that the balance of the binary arrangement, be it the romantic, the mother-son, or father-daughter couple, may be temporarily restored. We see the process of victimage in full force in Hedda Gabler. In fact, we see little else. First, Ibsen prepares us for the bourgeois tragedy of a man in love who is brought to financial ruin by a ruthless woman. Then we see Hedda being victimized by her husband and his aunt, and we see her in turn victimizing the aunt and the servant. The arrival of Thea provides us with another, more likely possibility for victimage- 
the unprotected woman who has left her home to be with her lover, who requires her protection rather than offering her any shelter against opprobrium. Discussed both as victim, "the black sheep of the family," and as victimizer, Lövborg, like Tesman, is another candidate for a more and more frenzied search for victimage. The Dionysian imagery, despite the seemingly commonplace circumstances, provides an apt reminder of the shift that has taken place in theater from classicism to realism in terms of the spaces in which violence occurs: the street, the marketplace, the Senate in Coriolanus; the street and exceedingly public salon of Le misanthrope; and finally the drawing room and "inner" space of Hedda Gabler.

We also see a domestication of violence that directs itself against children, symbolic or unborn though they may be, both as obstacles to romance and as inextricable ties between parents. The Oedipus complex may prove to be the ultimate bourgeois expression of male and female jealousy of the intrusive third party, who conveniently is the most easily victimized intruder as well. In its critique of domesticity and class pretentions to moral superiority, Hedda Gabler makes nonsense of the bourgeois ideal of the hearth as refuge from the cruel world of agonistic competition and of the then-current scientific theories of evolutionary superiority and eugenics.

Ultimately, then, what antigeneric drama does is refuse us the easy consolation of a resolved sacrificial crisis. In the sacrificial ritual "the animal selected as victim is led without apparent constraint in a procession to the altar.... The ritual takes care to obtain the animal's consent by a sign of the head ... of its assent at the moment of libation in order to believe that no injustice had indeed been committed." 28 The tragic heroes as well as the comic vices accommodate the audience in assenting to their own sacrifice either by recognizing that their fate is their own fault or by being so unyielding as to demand their expulsion and defeat. The heroes in antigeneric drama are an uneasy bunch to live with. They act in ways that implicate them in the process of victimage; they expose themselves as unprotected characters must not do, but they resist victimage. Even when they go to a willed death, like Hedda, they do so on their own terms and to frustrate the sacrificial fate prepared for them, that is, to turn sacrifice into what it rightly ismurder. The plots of these plays, tending toward indeterminacy of genre and thus theatrical improbability, give the game away by swaying audiences in various directions at various times, making audiences uncertain about their own responses, their own ability to detect the

${ }^{28}$ Detienne, “Culinary Practices," 9-10. 
truth. This is the ultimate gift of antigeneric drama: destabilizing our certainties, making us uneasy, giving us a glimpse of the violent processes in which we participate daily without recognizing them for what they are so long as violence is kept from affecting us directly. A split vision forbids mob gatherings; our own desire to do away with unpleasant people, coupled with our consciousness of a process in which victims are chosen for reasons other than their deserving to be victims, makes for a reflexivity without catharsis. We carry the bitterness of this spectacle with us.

It is perhaps all too easy to detect the power and designs of theatrical genre in a century in which theater has become normatively nongeneric and altogether borderline as an art form. I suspect that the forms that acculturate us to accept the horrors of our world and our implicit participation in them remain hidden to us, in their artistic imaginings as well as in their daily manifestations. But my hope is that we will continue to remain skeptical of victorious truths, that we will resist the power of too unanimous a persuasion, from whatever quarter it may come. And thus I argue against too vast a success for my own argument. What is at stake in such resistance, literally, is our lives. 